\title{
TAX INCENTIVES FOR MICRO ENTERPRISES - LATVIA'S EXPERIENCE
}

Inguna Leibus ${ }^{1}$, Dr.oec., professor

Latvia University of Life Sciences and Technologies

\begin{abstract}
The author continues studies on tax incentives for micro enterprises. Latvia has introduced a special tax regime - a micro-enterprise tax (MET), the improvement of which still continues to reduce its application for unfair tax competition. Following significant changes in the tax regulation, the popularity of MET in Latvia has decreased; though, it is still high, especially in the service sector. The micro-enterprise tax shall be retained considering the reduction of administrative and tax burdens; however, it is recommended to introduce a payment for every employee from his/her actual salary in addition to the payment from the enterprise turnover to ensure the tax sustainability and to improve the social security of micro-enterprise (ME) employees. Latvia's experience may be useful also for other countries, especially those with high unemployment and illegal employment rates, to stipulate involvement of the population in legal employment.
\end{abstract}

Key words: tax incentives, micro-enterprise, small business, social insurance, tax policy. JEL code: H21, H25, J30.

\section{Introduction}

A special tax on micro-enterprises has been created as fiscal instrument to support small business in Latvia. The MET was introduced on 1 September 2010 with the aim to create the necessary preconditions for the population having lost employment due to the economic crisis to start business, to reduce administrative requirements and to simplify the tax calculation. The initial aim had to be changed after the crisis with the economic recovery and decline of unemployment. The reduction of administrative and tax burden on ME was still topical; though, simultaneously there was a requirement to observe the common public interests in the sphere of fair competition and social security. The very rapid increase in the application of the MET regime was the reason for such a requirement. The increase was promoted not only by the reduced administrative burden on ME but mainly by lower tax burden and lower labour costs compared with the general tax regime. The MET created two basic problems: distortion of competition in business and insufficient social security of employees working in ME. The advanced hypothesis: the MET regime is widely applied as tax incentive for micro-enterprises in Latvia; though an improvement of the provisions is required to ensure its sustainability. Therefore, the research aim is to provide solutions for the improvement of micro-enterprise tax to ensure the sustainability of MET regime. The following tasks are derived from the research aim: 1) to study the recent scientific publications on tax incentives for micro-enterprises in the EU Member States; 2) to analyse the latest statistical data on the application of the MET regime in Latvia; 3) to develop recommendations for the improvement of the MET regime. The research employs monographic and descriptive statistical methods and covers the period from the introduction of MET in 2010 to 2018; however, a profound analysis was dedicated to the tendencies after 2016 when additional measures were introduced to restrict the application of the MET regime in Latvia.

\section{Research results and discussion}

In Latvia, the introduction of MET has led to several positive features in the economy, for example, decrease of illegal employment and increase in the number of newly established enterprises. However, this undoubtfully had also negative consequences, of which two the most essential are: 1 ) unequal tax competition leading to particularly favourable tax reduction for the MET payers; 2) social

\footnotetext{
${ }^{1}$ Corresponding author. Tel.: +37129458010

E-mail address: inguna.leibus@llu.Iv.
} 
security of employees of the MET payers is exposed to risk, especially if the MET regime has been chosen purposefully to reduce labour costs (Leibus, 2014).

Several researchers in Latvia have pointed on the negative consequences of the MET regime. The author partly agrees with the statement of Juruss, Kuma and Neimane that the present MET regime negatively affects the development of business environment in Latvia, since 1) it has not sufficiently facilitated employment; 2) it creates social security problems for people working under the MET regime and 3) the MET regime is used for tax optimisation (Juruss, Kuma, Neimane, 2017). Nevertheless, the author would like to emphasise that the negative consequences of the MET regime may not reject its positive impact; thus, the application of MET as fiscal instrument for the support of micro-enterprises may be continued; yet, it requires improvement. However, the author cannot agree with Prohorovs and Bistrova that MET is not applicable to self-employed (Prohorovs, Bistrova, 2017). The simplicity of tax calculations provided by the MET regime can contribute most to the activity of these taxpayers.

It is very positive that the MET significantly reduces the administrative burden on microenterprises and simplifies the tax calculation (Leibus, 2012). The authors Bergner and Heckemeyer in their research have analysed small and medium-sized enterprises (SME) in 27 European countries between 2004 and 2010, and they have concluded that small-sized enterprises really consider possibility to choose a simplified tax accounting; hence, choosing an appropriate type of business activity (Bergner, Heckemeyer, 2017). Consequently, the mentioned authors confirm the idea on the necessity of a special tax regime for small enterprises to reduce administrative requirements. There are relatively few EU Member States with a special tax regime for micro-enterprises; basically, the corporate income tax reliefs are set for companies during their first years of operation or investment support.

Bergner with the co-authors Bräutigam, Evers \& Spengel indicate that disproportionate tax compliance costs for small-sized enterprises are the most significant argument for the application of a special tax regime. In general, the policy makers shall shift their attention from providing discriminatory incentives to developing a generally neutral and simple tax system that would be beneficial to both small and large enterprises (Bergner, Bräutigam, Evers, \& Spengel, 2017).

It should be considered that Latvia has a unique experience in creating a MET and there had been No possibility to learn from other countries. Only the implementation of this intention into the practice has identified the weaknesses or "tax holes", which some entrepreneurs urgently used to reduce the tax burden. The law regulating the application of a MET has been amended several times since the tax introduction. The amendments included ever-new provisions of the law to "stifle holes" in the legal enactments that allowed undesirable and inappropriate tax planning not complying with the MET aim and unequal competition among companies paying taxes consistent with the general tax regime and the ones working under the MET regime. Also, the initially set MET in the amount of $9 \%$ of turnover was too desirable for the small business; thus, it was gradually increased from $9 \%$ to $15 \%$ in 2018 (Table 1). The redistribution of collected MET was gradually changed with the increase of the MET rate; hence, increasing the amount of redistributed mandatory state social insurance contributions (MSSIC) from $65 \%$ to $80 \%$ in 2018. 


\section{The most significant criteria and indicators of the MET in Latvia between 2010} and 2018

\begin{tabular}{|l|c|c|}
\hline \multicolumn{1}{|c|}{ Indicator } & $\mathbf{2 0 1 0}$ & $\mathbf{2 0 1 8}$ \\
\hline Turnover, EUR & 100000 & 40000 \\
\hline Number of employees & 5 & 5 \\
\hline Monthly salary (income), EUR & 711 & 720 \\
\hline $\begin{array}{l}\text { One person may be the owner of only one enterprise being the MET } \\
\text { payer }\end{array}$ & yes & yes \\
\hline One person may be employed only by one MET payer at the time & no & yes \\
\hline MET rate, \% of turnover & 9 & 15 \\
\hline Taxes included into the MET & \multicolumn{2}{|c|}{ MSSIC, PIT, CIT } \\
\hline Redistribution of the MET for the social insurance of employees, \% & 65 & 80 \\
\hline
\end{tabular}

PIT - personal income tax, CIT - corporate income tax

Source: Micro-enterprise Tax Law, 2010, latest amendments ....

Bergner S.M. (2017), a German researcher, in his PhD thesis has also analysed the experience of Latvia in the introduction of the MET regime by indicating on two basic policy consequences. First, policy makers, when designing tax incentives for SME, shall avoid explicit size thresholds, especially those related with the employment thresholds, since this is likely to trigger a response reaction by reducing the growth of paid employment and companies. Second, legislators shall be aware not to offer too favourable regimes resulting in strong distortion of competition among companies (Bergner, 2017). It must be agreed that S.M. Bergner has precisely identified risks faced by the legislators in Latvia.

In the case of Latvia, the problem with very strictly set thresholds for the company size was solved by allowing not to calculate additional taxes within the year in which the criteria set for the MET payer are exceeded, i.e. the turnover has grown but the growth does not exceed $30 \%$ and/or the number of employees has increased by 1-2 employees compared with the previous year. ME could use such an opportunity from 2014 onwards. As a result of the changes, the enterprise growth in one taxation year does not increase the tax burden on a ME. However, the enterprise may not apply a preferential tax regime in the following year after exceeding the criteria. Therefore, after the change of a tax regime the amount of taxes to be paid significantly increased for the enterprise, especially those operating in labour-intense sectors. This condition has promoted an artificial fragmentation of enterprises in Latvia, i.e. one and the same business is performed through two or even more enterprises by registering the subsequent enterprise on the name of a trustworthy person. In addition, these enterprises were not prohibited of employing the same employees. Therefore, the same employee could have been employed by several enterprises paying the MET, and hence s/he did not financially suffer from the restriction that the maximum salary in MET paying company may not exceed EUR 720 per month. In practice, the possibility for one owner to establish several enterprises operating in the MET regime was restricted already form the very beginning of the MET introduction; though, the possibility of being employed by more than one micro-enterprise is gradually eliminated only from 2018 (Table 1).

The preferential tax regime for ME in Latvia was so desirable that the number of MET payers increased rapidly with every year, and already $14.05 \%$ of all taxpayers had chosen the MET regime in 2016. The negative effects of the MET such as distortions of tax competition and decrease of social security for employees became increasingly evident; thus, it was necessary to reduce the appealingness of the MET regime. Basically, this appealingness was expressed as a lower tax burden 
compared with the general tax regime. Therefore, the MET rate was gradually increased from 2017. Meanwhile, in 2018, the criterion on annual turnover was reduced from EUR 100000 to EUR 40000 to ensure that the MET regime is used only by micro-enterprises. As a result, the number and proportion of the MET payers started to decline; in 2018, the respective decline was $9.98 \%$ and 1.44 percentage points (pp) compared with 2016 (Table 2), while the amount of paid tax continued to increase $(+41.73 \%)$.

\section{Changes in the number of MET payers and MET revenues and their share in} Latvia

\begin{tabular}{|l|c|c|c|c|}
\hline \multicolumn{1}{|c|}{ Indicator } & $\mathbf{2 0 1 6}$ & $\mathbf{2 0 1 7}$ & $\mathbf{2 0 1 8}$ & $\mathbf{2 0 1 8 / 2 0 1 6}$ \\
\hline Number of MET payers on 1 January & 49293 & 45411 & 44373 & $-9.98 \%$ \\
\hline Total taxpayers on 1 January & 350924 & 352390 & 352006 & $+0.31 \%$ \\
\hline Share of the MET payers & 14.05 & 12.89 & 12.61 & $-1.44 p p$ \\
\hline MET (mIn, EUR) & 63.5 & 82.1 & 90.0 & $+41.73 \%$ \\
\hline Labour taxes (PIT + MSSIC) (mIn, EUR) & 4483.9 & 4922.7 & 5232.1 & $+16.69 \%$ \\
\hline MET/ labour taxes, \% & 1.42 & 1.67 & 1.72 & $+0.30 \mathrm{pp}$ \\
\hline
\end{tabular}

Source: author's calculations based on the statistical data of the SRS of the Republic of Latvia

The MET regime is very desirable by small entrepreneurs not only because of the reduced tax burden. The administrative burden is also considerably diminished, since paying the MET of $15 \%$ (initially $9 \%$ ) of all enterprise income or turnover, the MET replaces several other taxes that the enterprise would have to pay under the general tax regime. No labour taxes are to be paid separately, which means that net salary equals the gross salary for the employees operating under the MET regime. Though, to ensure the tax revenue distribution consistent with their aim, the State Treasury redistributes the collected MET by redirecting $80 \%$ (initially $65 \%$ ) of the collected MET to the social insurance contributions of employees, while the rest of the tax is redistributed between PIT and CIT. This ensures a simple tax calculation and administration as well as retains a personalised social insurance of every employee, as the amount of insurance depends on the tax contributions made.

Comparing the amount of MET totally collected in Latvia with the amount of PIT and MSSIC, there is a positive trend (Table 2). Despite the decrease in the number of MET payers, the ration of collected MET to labour taxes grows, mainly due to the increase in the MET rate. However, a topical problem is still the social security of employees operating under the MET regime, which is not only less security for the employee itself but it may be a burden for the rest of the society, providing the minimum social guarantees for an employee of the MET regime in case social contributions made for him/her are not sufficient for the national minimum security.

Moreover, unlike the general tax regime, where the social insurance of employees is proportional to their salary, in case of the MET regime, it is more dependent on the size of the enterprise's turnover, while the amount of salary has a slight impact on social security, since $80 \%$ of the MET which is redistributed as the MSSIC is distributed among employees proportionally to the amount of salary of each employee. For example, if a ME has a turnover of EUR 2000 per month, then $15 \%$ of the MET equals EUR 300 and EUR 240 are redistributed as the MSSIC. If it is assumed that there are two employees in the enterprise, one of which receives EUR 700 and the other receives EUR 500 per month, then the share of the first employee's salary is $58.3(3) \%$ of the salary fond $(700 /(700+500))$ and EUR 140 are redirected for his/her social insurance, while the remaining EUR 100 are redirected for the social insurance of the second employee. When recalculating according to the MSSIC rate of $35.09 \%$, it may be concluded that the social insurance object, from which the social security of these 
employees depends, is almost EUR 400 for the first employee and almost EUR 285 for the second employee. In addition, nevertheless the salary of both employees exceeds the minimum salary in the country (EUR 430 in 2019), the social insurance object is less than the minimum salary. Therefore, it may be concluded that the social security for the majority of employees working in enterprises paying the MET will be lower in the future than those working under the general tax regime. In addition, health insurance in Latvia from 2019 is linked to the tax payments, and despite the fact that this is a legal tax payment regime, the employees working in enterprises paying the MET are left outside this system.

Hence, considering the above-mentioned, the number of employers and employees in the MET regime has also started to decrease from 2017 , by $12.36 \%$ and $9.92 \%$, respectively, compared with the previous year (Table 3). The author has No data available for 2018 but it can be asserted that the decline still continues. A positive trend is the increase in the average number of employees in both the companies paying tax in the general tax regime (by $1.60 \%$ ) and those paying the MET $(3.03 \%)$, which shows the stability of companies and a relatively slow growth.

Table 3

Changes in the number of employers and employees, and salary in the general tax and the MET regimes in Latvia between 2016 and 2017

\begin{tabular}{|c|c|c|c|c|c|c|}
\hline \multirow[b]{2}{*}{ Indicator } & \multicolumn{3}{|c|}{ General tax regime } & \multicolumn{3}{|c|}{ MET regime } \\
\hline & 2016 & 2017 & $\begin{array}{l}2017 / \\
2016, \%\end{array}$ & 2016 & 2017 & $\begin{array}{l}2017 / \\
2016, \%\end{array}$ \\
\hline Number of employers & 79369 & 78807 & -0.71 & 45113 & 39535 & -12.36 \\
\hline $\begin{array}{l}\text { Number of employees, on average per } \\
\text { year }\end{array}$ & 742120 & 748791 & 0.90 & 74473 & 67084 & -9.92 \\
\hline $\begin{array}{l}\text { Number of employees, on average } \\
\text { employed by one employer }\end{array}$ & 9.35 & 9.50 & 1.60 & 1.65 & 1.70 & 3.03 \\
\hline Average salary, EUR & 785 & 903 & 15.03 & 551 & 566 & 2.72 \\
\hline
\end{tabular}

Source: author's calculations based on the statistical data of the SRS of the Republic of Latvia

The average salary in the companies paying taxes under the general tax regime grows faster than those paying taxes under the MET regime, by $15.03 \%$ and $2.72 \%$, respectively, compared with the previous year (Table 3). This may be explained by the restriction regarding the income of a $M E$, which may not exceed EUR 720 per month. This is another reason why the MET regime is not so desirable any more, especially in the sectors with higher average salary (Table 4). 


\section{TOP-10 sectors in Latvia with the largest proportion of MET payers and the average salary in these sectors}

\begin{tabular}{|c|c|c|c|c|c|}
\hline \multirow[t]{2}{*}{$\begin{array}{l}\text { NACE } \\
2 \text { code }\end{array}$} & \multirow[t]{2}{*}{ Sector } & \multicolumn{2}{|c|}{$\begin{array}{c}\text { MET, \% of the } \\
\text { number of } \\
\text { taxpayers in the } \\
\text { sector }\end{array}$} & \multirow{2}{*}{$\begin{array}{c}2018 / \\
2016 \\
p p\end{array}$} & \multirow{2}{*}{$\begin{array}{l}\text { Average } \\
\text { salary in } \\
Q 1-Q 3 \text { of } \\
2018 \text {, EUR } \\
\text { per month }\end{array}$} \\
\hline & & $\begin{array}{c}01.01 . \\
2016\end{array}$ & $\begin{array}{r}01.01 \\
2018\end{array}$ & & \\
\hline 81 & Services to buildings and landscape activities & 36.0 & 39.0 & 3.0 & 477 \\
\hline 74 & $\begin{array}{l}\text { Other professional, scientific and technical } \\
\text { activities }\end{array}$ & 8.3 & 32.7 & 24.4 & 768 \\
\hline 62 & $\begin{array}{l}\text { Computer programming, consultancy and related } \\
\text { activities }\end{array}$ & 35.5 & 32.3 & -3.2 & 1965 \\
\hline 97 & $\begin{array}{l}\text { Activities of households as employers of domestic } \\
\text { personnel }\end{array}$ & 6.7 & 32.3 & 25.6 & 263 \\
\hline 59 & $\begin{array}{l}\text { Motion picture, video and television programme } \\
\text { production, sound recording and music publishing } \\
\text { activities }\end{array}$ & 26.3 & 31.1 & 4.7 & 702 \\
\hline 71 & $\begin{array}{l}\text { Architectural and engineering activities; technical } \\
\text { testing and analysis }\end{array}$ & 32.0 & 30.7 & -1.3 & 961 \\
\hline 82 & $\begin{array}{l}\text { Office administrative, office support and other } \\
\text { business support activities }\end{array}$ & 35.4 & 30.0 & -5.4 & 1069 \\
\hline 69 & Legal and accounting services & 32.9 & 29.0 & -3.8 & 1290 \\
\hline 53 & Postal and courier activities & 20.0 & 28.4 & 8.3 & 693 \\
\hline 43 & Specialised construction activities & 25.6 & 27.5 & 1.9 & 656 \\
\hline
\end{tabular}

Source: author's calculations based on the statistical data of the SRS of the Republic of Latvia

As noted before, the largest number and proportion of the MET payers was in 2016 when they accounted for more than $14 \%$ of all registered taxpayers. In the coming years, the number of MET payers as well as their proportion was gradually decreasing. Nevertheless, the proportion of MET payers is still very high in some sectors (Table 4). In addition, there is still an increase in the proportion of MET payers in several sectors, for example, almost one third of all taxpayers in the sector "Activities of households as employers of domestic personnel" are enterprises operating under the MET regime ( $32.3 \%$ in 2018), the increase is 25.6 pp within two years, while the increase of the proportion of MET payers is $24.4 \mathrm{pp}$ in the sector "Other professional, scientific and technical activities" and $8.3 \mathrm{pp}$ in the sector "Postal and courier activities". The sector "Services to buildings and landscape activities" has invariably the largest proportion of the MET payers (36 \%-39\%). Since the introduction of the MET regime, there has been a clear trend that this regime is mainly chosen by service sectors as it is significantly more advantageous in labour-intense rather than materialintense sectors. However, according to the statistics of recent years, the number of MET payers is declining more rapidly in the sectors with higher average salary, e.g. "Office administrative, office support and other business support activities" by 5.4 pp, "Legal and accounting services" by $3.8 \mathrm{pp}$ and "Computer programming, consultancy and related activities" by $3.2 \mathrm{pp}$. In most of the sectors listed in Table 4, the average salary is lower than the average salary in Latvia (according to the Central Statistical Bureau (CSB), the average salary in the private sector was EUR 957 in Q1 of 2018), except for four sectors where the salaries exceed the average salary and where the proportion of MET payers gradually decreases.

Analysing by sub-sectors, it is even more apparent that the MET regime is chosen in the service sector. One third of the MET payers registered in Latvia are employed in the 10 sub-sectors (Table 5). The sub-sector "Other personal service activities not classified elsewhere" represents the largest 
number of the MET payers. In 2018, they account for $8.6 \%$ of the total MET payers registered in Latvia.

TOP-10 sub-sectors in Latvia with the largest number of MET payers and their changes

\begin{tabular}{|l|l|c|c|c|c|}
\hline & \multicolumn{1}{|c|}{ Sub-sector } & $\begin{array}{c}\mathbf{0 1 . 0 1 .} \\
\mathbf{2 0 1 7}\end{array}$ & \multicolumn{2}{c|}{$\mathbf{0 1 . 0 1 . 2 0 1 8}$} \\
\cline { 3 - 5 } $\begin{array}{c}\text { NACE } \\
\mathbf{2} \\
\text { code }\end{array}$ & \multicolumn{1}{|c}{} & & $\begin{array}{c}\text { \% of the } \\
\text { number of } \\
\text { MET } \\
\text { payers in } \\
\text { Latvia }\end{array}$ & $\begin{array}{c}\mathbf{2 0 1 8 /} \\
\mathbf{2 0 1 7}\end{array}$ \\
\hline 9609 & Other personal service activities n.e.c. & 4276 & 3824 & 8.6 & -10.6 \\
\hline 6920 & $\begin{array}{l}\text { Accounting, bookkeeping and auditing } \\
\text { activities; tax consultancy }\end{array}$ & 2203 & 2151 & 4.8 & -2.4 \\
\hline 0220 & Forestry and logging & 1513 & 1418 & 3.2 & -6.3 \\
\hline 4120 & $\begin{array}{l}\text { Construction of residential and non- } \\
\text { residential buildings }\end{array}$ & 1309 & 1224 & 2.8 & -6.5 \\
\hline 9602 & Hairdressing and other beauty treatment & 1202 & 1223 & 2.8 & 1.7 \\
\hline 4520 & Maintenance and repair of motor vehicles & 1065 & 1049 & 2.4 & -1.5 \\
\hline 6201 & Computer programming activities & 996 & 1009 & 2.3 & 1.3 \\
\hline 7022 & $\begin{array}{l}\text { Business and other management } \\
\text { consultancy activities }\end{array}$ & 1001 & 945 & 2.1 & -5.6 \\
\hline 4399 & $\begin{array}{l}\text { Other specialised construction activities } \\
\text { n.e.c. }\end{array}$ & 900 & 918 & 2.1 & 2.0 \\
\hline 6910 & Legal activities & 858 & 812 & 1.8 & -5.4 \\
\hline
\end{tabular}

Source: author's calculations based on the statistical data of the SRS of the Republic of Latvia

A large number of the MET payers is also registered in the sub-sector "Accounting, bookkeeping and auditing activities; tax consultancy" (4.8\% of the total MET payers in Latvia). Mostly they are outsourced accountants who would have No difficulties to calculate taxes also in the general tax regime; though, they choose to pay the MET. Therefore, it provides not only the possibility to reduce the tax burden, which allows reducing the costs for accounting services, but also to reduce the administrative burden by a significant simplifying of the tax calculation and the declaration procedure. In addition, it has to be taken into account that a large part of population in Latvia chooses to earn additional income in other jobs apart from the basic employment incl. self-employment by providing different types of services. According to the data of the CSB of the Republic of Latvia, for example, in 2017 , only $29.6 \%$ of employees in the sector "Legal and accounting services" (NACE code 69) and $37 \%$ of the employed in the sector "Other personal service activities" (NACE code 96) worked in the private sector with the work time tracking. This, in turn, means that very often a ME is not the only source of income for the MET payers but it is an additional source of income, and it is important that it is easy to calculate and pay the tax on this additional income.

According to the statistics, the MET regime is still very popular in Latvia even after the introduction of less favourable legal provisions. Considering the fact that the MET regime has greatly reduced the administrative burden on $\mathrm{ME}$, it has to be retained also in the future by improving the provisions related with the social insurance of employees. The problem could be solved by including two tax objects into the MET calculation base - turnover and income (salary). A fixed percentage of the actual salary shall be set as an additional payment to the employer for every employee for his/her social insurance. This means not a constant payment or a payment from a certain size, such as the minimum salary but from the actual activity Figures of an enterprise. In Latvia, an attempt to introduce additional MSSIC on micro-enterprises from the minimum salary set in the country has 
already suffered a failure. This is very significant particularly for start-up companies that have difficulties to predict both the size of turnover and salaries as they often depend on the company's success to conquer the market and develop. Moreover, it is very important to calculate the correct tax proportion or rate for each tax object. It is recommended to keep the tax rate on turnover lower than the rate on income (salary), which would make the MET more desirable also in material-intense sectors that would have to pay a higher tax share on turnover, while lower - on salaries paid.

In the case of Latvia, it is now advisable to introduce a payment for the pension insurance of a ME employees in the amount of $5 \%$ and health insurance in the amount of $1 \%$ from the salary in addition to the tax on the ME turnover. An employer would make the tax payment at its own expense. The introduction of an additional tax payment would retain the simplicity of the MET regime and the gross and net salaries would still remain the same. In such a case, the administrative burden would not increase. The tax burden for the MET payers would increase by about 2-5\%, calculating against the ME turnover. The increase in the tax burden of each enterprise would depend on the proportion of expenditure on salaries; if it is $80 \%$ of turnover, the tax burden would increase by $4.8 \%$ but if it is $40 \%$, then by $2.4 \%$. Nevertheless, tax payments for each ME would grow considerably by around 20-30\%, since the tax is relatively low at present. Probably the tax rate on turnover should be slightly reduced to minimise the negative effect; this could be done by finding the optimum balance between these two tax objects. As an additional measure to compensate for the tax increase, it is advisable to increase the criterion on income, which has not been changed since 2010, and thus, it lags behind the average net salary in the country that exceeds EUR 720 in 2019. Currently, this restriction hinders the growth of many ME.

To convince the MET payers of the necessity for an additional tax object, it is very essential for the society to explain the potential risks of making No changes and the benefits of changes. The payment for pension insurance of $5 \%$ of the actual salary is recommended, since it is the same as the payment for self-employed introduced from 2018. The payment of $1 \%$ for health insurance, in turn, has been introduced already from 2017 for all employees except for the employees of the MET payers. It is advisable to change the proportion of the MET object in the coming years by increasing the tax proportion on income (salaries) and decreasing the tax on turnover respectively.

The introduction of an additional tax payment would considerably increase the MET collected in the country. If it is calculated consistent with the statistical data of 2017 (Tables 2 and 3), the average salary for 67000 people employed by the MET payers is EUR 566 per month or EUR 6792 per year, then the payment of $6 \%$ of the salary would increase the MET payments by approximately EUR 27 million or 33 \%. The reduction of a "tax shock" for companies changing the tax regime from the MET regime to the general tax regime is a positive aspect of such a tax increase in Latvia, because currently the tax burden when changing the status of a taxpayer may grow even 2-3 times, directly at the expense of labour taxes. The proposed changes would reduce the tax burden difference between the two tax regimes, which would diminish the consequences of unequal tax competition.

\section{Conclusions, proposals, recommendations}

1) The present studies confirm that micro-enterprises need special tax support and incentives; though, they may not be too profiTable that would distort the tax competition among companies operating under different tax regimes.

2) In Latvia, a number of significant changes has been introduced in recent years to amend the legal and regulatory enactments of the MET to improve this tax regime and reduce its application for unfair tax competition. 
3) The popularity of the MET regime in Latvia that is just slightly declined after the introduction of less favourable amendments for entrepreneurs confirms that micro-enterprises have appraised the positive impact of the MET regime on the reduction of the administrative and tax burdens, especially in the service sector. This tax regime is not suiTable for material-intense sectors or a lower tax rate shall be applied to these sectors if the tax is calculated on the enterprise turnover.

4 ) It is recommended to introduce a payment for each employee at $5 \%$ from the actual salary for an employee's pension insurance and $1 \%$ - for the health insurance to improve the social security of the employees of the MET payers in Latvia. These payments would be easy to administer. It is recommended to increase the criterion on income (salary) or/and slightly decrease the MET rate on the company turnover to compensate for the increase in the tax burden on micro-enterprises.

5) Latvia's experience is particularly recommended for countries with high rates of unemployment and illegal employment to promote the involvement of population in legal employment. However, it is advisable to include also the actual salary of employees in the MET object in addition to the company turnover not to reduce the social security of micro-enterprise employees.

\section{Bibliography}

1. Bergner, S., Bräutigam, R., Evers, M., \& Spengel, C. (2017). The Use of SME Tax Incentives in the European Union, p.125.

2. Bergner, S.M., \& Heckemeyer, J.H. (2017). Simplified Tax Accounting and the Choice of Legal Form. European Accounting Review, 26(3), pp. 581-601.

3. Bergner, S.M. (2017). Tax Incentives for Small and Medium-sized Enterprises - a Misguided Policy Approach? Doctoral dissertation, p.350.

4. CSB Statistics. Retrieved: https://www.csb.gov.Iv/Iv/statistika/statistikas-temas/socialie-procesi/darbasamaksa/meklet-tema/2385-darba-samaksas-parmainas-2018-gada-2. Access: 7.01.2019.

5. Juruss, M., Kuma, E., \& Neimane, L. (2017). Optimal Taxation of Small Businesses. In: Economic Science for Rural Development Conference Proceedings (No 46), pp.242-249.

6. Leibus I. (2014) Problematic Aspects of Micro-Enterprise Tax in Latvia. Economics and Rural Development. Research papers, Vol. 10, No 1, pp. 32-38.

7. Leibus, I. (2012). Micro-Enterprise Tax as Means of Promoting Entrepreneurship in Latvia. Science and Studies of Accounting and Finance: Problems and Perspectives: Scientific Journal No 1 (8). Aleksandras Stulginskis University, pp. 116-120.

8. Mikrouznemumu nodokla likums (Micro-enterprise Tax Law): LR likums (2010) Retrieved: http://www.likumi.lv. Access: 7.01.2019.

9. Prohorovs, A., Bistrova, J. (2017) The evaluation of microenterprise tax regime efficiency in Latvia. In: Economic Science for Rural Development Conference Proceedings (No 46), pp.317-328.

10. VID statistika (SRS Statistics). Retrieved: http://www.vid.gov.Iv/default.aspx?tabid=11\&id=5729\&hl=1. Access: 07.01.2019. 